\title{
Analisis Pengaruh Behavioural Finance Terhadap Pengambilan Keputusan Investasi Investor di Kepulauan Riau
}

\author{
Candy \\ Universitas Internasional Batam \\ candy.chua@uib.ac.id \\ Kellen Vincent \\ Universitas Internasional Batam \\ kellenv17@gmail.com
}

\begin{abstract}
Abstrak Perkembangan ekonomi global yang semakin maju dan cepat akibat adanya perkembangan teknologi menyebabkan kegiatan berinvestasi semakin dipermudah. Hal tersebut membuat minat investasi di Indonesia selama empat tahun terakhir berkembang sangat pesat. Akan tetapi, peningkatan jumlah investor dan banyaknya keuntungan yang ditawarkan tidak menggambarkan secara nyata kinerja investasi para investor itu sendiri. Kinerja investasi yang baik juga memiliki korelasi kuat dengan pengambilan keputusan investasi yang baik dan rasional. Seorang investor yang baik biasanya akan membuat suatu keputusan investasi yang rasional, tetapi nyatanya para investor sering kali membuat keputusan investasi yang buruk akibat pengaruh faktor psikologis dalam diri mereka sendiri. Sebagai contohnya, pada masa pandemi COVID-19 ini, IHSG Indonesia bahkan seluruh negara mengalami penurunan drastis akibat kepanikan para investor. Dari contoh tersebut dapat kita ketahui bahwa peran faktor psikologis sangatlah penting. Penelitian ini dibuat dengan tujuan untuk mencari tahu dan menguji faktor-faktor behavioural finance yang memiliki pengaruh kepada para investor di Kepulauan Riau dalam proses pengambilan keputusan investasi. Faktor-faktor behavioural finance yang diuji pada penelitian ini adalah representativeness bias, availability bias, overconfidence bias, loss aversion bias, dan anchoring and adjustment bias. Sampel yang digunakan sebagai bahan pengujian berjumlah 133 responden yang merupakan investor aktif di Kepulauan Riau. Hasil pengujian menunjukkan bahwa, variabel loss aversion dan anchoring \& adjustment bias berpengaruh positif terhadap proses pengambilan keputusan investasi para investor di Kepulauan Riau, sedangkan variabel representativeness bias, overconfidence, dan availability bias tidak memiliki pengaruh yang signifikan.
\end{abstract}

Kata Kunci Bias Perilaku, Keputusan Investasi, Investor, Bias Kognitif, dan Bias Emosional

\section{PENDAHULUAN}

Perkembangan ekonomi global yang sangat pesat belakangan ini ditambah dengan adanya dukungan dari perkembangan teknologi membuat persaingan di dunia 
bisnis semakin cepat dan memanas. Hal ini mengakibatkan banyak perusahaan di Indonesia yang berlomba-lomba untuk mencari suntikan dana dari masyarakat agar mampu memperluas bisnis yang sudah mereka miliki dan bisnis yang sedang mereka rencanakan di masa depan melalui pasar modal (saham).

Korelasi dari kedua fenomena tersebut memberikan dampak dan dorongan positif terhadap peningkatan minat investasi saham di Indonesia, sehingga membuat jumlah investor di Indonesia pada 4 tahun terakhir mengalami peningkatan yang sangat signifikan. Menurut data dari KSEI (2019), single investor identification (SID) yang tercatat di Indonesia selama tahun 2016 berjumlah 894.116 SID, pada tahun 2017 berjumlah 1.122.668 SID, dan pada tahun 2018 berjumlah 1.619.372 SID, sedangkan untuk tahun 2019 sendiri, per tanggal 29 November 2019, single investor identification (SID) yang tercatat berjumlah 2.409.075 SID. Data tersebut menunjukkan adanya peningkatan jumlah investor di Indonesia sebesar 169,44\% dari periode 2016 hingga periode November 2019.

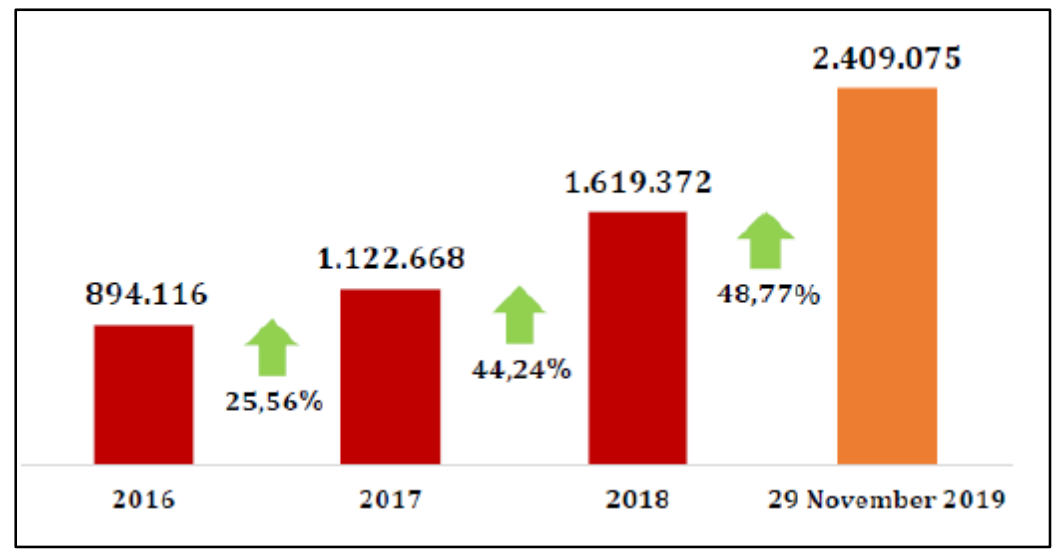

Sumber: KSEI (2019)

\section{Gambar 1 Grafik Pertumbuhan SID Periode 2016 - 29 November 2019}

Meningkatnya jumlah investor saham di Indonesia menjadi salah satu kabar gembira bagi perusahaan dan pemerintah, hal ini dikarenakan banyaknya dampak positif yang timbul dari peningkatan jumlah investor tersebut. Bagi perusahaan, peningkatan ini menjadi sebuah kesempatan besar bagi perusahaan untuk mencari dana dan memperbesar bisnis yang mereka miliki ataupun bisnis yang sedang mereka rencanakan. Sedangkan bagi pemerintah, peningkatan jumlah investor ini diharapkan juga dapat meningkatkan kestabilan ekonomi Indonesia kedepannya.

Bagi masyarakat Indonesia, berinvestasi di pasar modal menjadi sebuah sarana untuk mencari keuntungan atau pengembalian atas dana yang telah ditanamkan. Keuntungan atau pengembalian yang biasanya didapatkan masyarakat dari kegiatan investasi saham berupa dividen dan capital gain. Akan tetapi, untuk mendapatkan keuntungan atau pengembalian yang besar tersebut tentu tidaklah mudah, masyarakat dipaksa untuk mampu menganalisis, cermat, dan bijak dalam memilih saham-saham yang sekiranya memiliki kinerja yang cukup bagus dan berkelanjutan.

Peningkatan jumlah investor dan banyaknya keuntungan yang ditawarkan dari investasi saham tidak semata-mata menggambarkan bahwa kinerja investasi individu maupun suatu negara juga akan baik ataupun meningkat. Kinerja investasi yang baik 
memiliki korelasi yang sangat kuat dengan pengambilan keputusan investasi yang rasional dan baik pula

Seorang investor yang rasional biasanya akan membuat keputusan investasi yang bijak dan cermat. Namun, kenyataanya seorang investor sering kali melakukan kesalahan dalam pengambilan keputusan investasi karena dipengaruhi oleh faktor psikologi dalam diri mereka. Menurut Aini dan Lutfi (2019), keputusan investasi yang diambil atau dibuat oleh seorang investor tidak selalu didasarkan pada pertimbangan yang rasional saja, melainkan juga terdapat aspek irasional di dalamnya yang berhubungan erat dengan kejiwaan seseorang atau yang lebih sering disebut sebagai Behavioural Finance / Behavioural Biases / Psychological Biases.

Sebagai contoh, pada tahun 2020 ini, para investor di pasar modal semakin ditantang untuk mampu mempertahankan kinerja investasi sahamnya, yaitu dengan cara tetap mempertahankan pengambilan keputusan investasi yang rasional dikondisi ekonomi global yang sedang memburuk akibat pandemi COVID-19. Menurut data dari Bursa Efek Indonesia (2020), IHSG (indeks harga saham gabungan) Indonesia pernah turun hingga menyentuh harga terendah diangka Rp 3.937,632 dikarenakan terjadi kepanikan dari para investor terhadap pandemi COVID-19 ini. Untuk itulah, bias perilaku ini penting untuk diketahui, dipelajari, dan dikuasai agar para investor semakin paham dan mampu mengendalikan dirinya dalam kondisi apapun dan tetap membuat keputusan investasi yang tepat dan rasional (Bursa Efek Indonesia, 2020).

Aini dan Lutfi (2019) dalam penelitiannya berhasil mengemukakan adanya pengaruh yang cukup signifikan dari faktor psikologi terhadap seorang investor dalam membuat suatu keputusan investasi di pasar modal. Keputusan investasi biasanya melibatkan yang namanya faktor kognitif (cognitive biases) dan faktor emosi (emotional biases) (Rehan \& Umer, 2017).

Faktor kognitif merupakan suatu bentuk bias yang berkaitan dengan cara seorang investor dalam memahami, mengatur, dan mengambil kesimpulan atas suatu informasi. Contoh dari faktor kognitif ini sendiri cukup beragam, seperti availability bias, representativeness bias, anchoring and adjustment bias, dan lain-lain. Faktor emosi merupakan suatu bentuk bias yang berkaitan dengan cara seorang investor dalam mendaftarkan suatu informasi dan mengambil suatu keputusan investasi, Contoh dari emotional biases ini adalah overconfidence bias, loss aversion bias, dan lain-lain (Antony and Joseph, 2017).

Seorang investor yang memiliki bias perilaku dalam melakukan kegiatan pengambilan keputusan investasi akan cenderung mengarah kepada pengambilan keputusan yang tidak tepat dalam berinvestasi. Akan tetapi, bagi investor yang mampu menguasai dan mengendalikan bias perilaku juga cenderung akan mengarah kepada pengambilan keputusan investasi yang baik pula. Semua itu kembali lagi kepada bagaimana seorang investor dalam menyikapi bias perilaku yang ada.

\section{LANDASAN TEORI}

\section{Investment Decision}

Investment Decision merupakan suatu proses dimana seseorang (investor saham) dalam menentukan suatu pilihan melalui tahap penetapan tujuan, tahap pencarian, dan tahan evaluasi informasi yang berhubungan dengan beberapa alternatif instrumen investasi. Hampir semua jenis investasi yang ada memiliki yang namanya ketidakpastian dan risiko di dalamnya. Risiko dan tingkat pengembalian menjadi salah-satu faktor penting dalam menentukan suatu keputusan investasi. Pengambilan keputusan investasi 
yang baik dan efektif dapat dilakukan dengan cara memilih instrumen investasi yang sesuai dengan tujuan investasi, tingkat pengembalian yang diharapkan, jangka waktu, dan tingkat risiko yang ada (Aini \& Lutfi, 2019). Seorang individu dapat sukses dalam melakukan investasi apabila mampu mengambil suatu keputusan investasi secara optimal dan rasional. Keputusan investasi yang tidak optimal dan rasional dapat disebabkan karena, ketidaksempurnaan informasi, anomali, bias psikologis, dll (Shah et al., 2018).

\section{Representativeness Bias}

Representativeness biases merupakan salah satu jenis heuristik kognitif yang menggambarkan kecenderungan seseorang (investor saham) dalam mengganggap suatu karakteristik sebagai suatu perwakilan dari seluruh fenomena yang ada terlepas dari ada atau tidaknya hubungan antara karakteristik tersebut dengan fenomena yang terjadi (Khan et al., 2017). Ani dan Ozari (2020) dalam penelitiannya menyatakan bahwa, representativeness bias merupakan salah satu faktor penting yang memiliki pengaruh signifikan poitif terhadap proses pengambilan suatu keputusan investasi yang irasional. Hal ini dikarenakan adanya kecenderungan para investor dalam mengkategorikan informasi baru berdasarkan pada pengalaman mereka di masa lalu. Para investor di Pasar Modal cenderung percaya bahwa, pelajaran atau pengalaman yang didapatkan dari kejadian di masa lalu dapat digunakan untuk memprediksi tantangan investasi dan pergerakan pasar di masa depan..

Kamaran et al. (2020) juga mendukung hal tersebut dengan menyatakan bahwa, pada umumnya para investor cenderung percaya akan adanya konsep kejadian berulang, dimana para investor berusaha mengamati pengalaman sebelumnya daripada melihat kemungkinan baru ke depannya. Hal tersebut menyebabkan para investor gagal untuk memahami bahwa hasil masa depan mungkin saja berbeda dari kejadian dan penilaian mereka sebelumnya.

\section{Anchoring \& Adjustment Bias}

Anchoring and adjustment biases merupakan salah satu jenis heuristik kognitif yang menggambarkan kecenderungan seseorang (investor saham) dalam memperkirakan sesuatu dengan cara membuat sebuah tebakan atau estimasi awal kemudian dilakukan penyesuaian dan diakhiri dengan terbentuknya tebakan atau estimasi akhir (Khan et al., 2017). Dangol dan Manandhar (2020) dalam penelitiannya mengemukakan adanya pengaruh signifikan positif dari faktor anchoring and adjustment bias kepada para investor dalam mengambil suatu keputusan investasi. Hal ini disebabkan karena adanya kecenderungan dari para investor yang menggunakan informasi awal sebagai pedoman dalam membuat suatu penilaian. Ketika seorang investor memiliki kecenderungan ini, maka semua kemungkinan, penilaian, dan keputusan lainnya hanya akan menjadi pelengkap saja, sehingga menimbulkan kesalahan dalam pengambilan keputusan investasi.

\section{Availability Bias}

Availability biases merupakan salah satu jenis heuristik kognitif yang menggambarkan kecenderungan seseorang (investor saham) untuk mengandalkan suatu informasi yang sudah tersedia sebelumnya (Khan et al., 2017). Kamaran et al. (2020) dalam penelitiannya mengemukakan adanya pengaruh yang signifikan positif dari faktor availability bias terhadap proses pengambilan keputusan investasi. Hal ini dikarenakan para investor yang memiliki kecenderungan hanya menggunakan informasi yang tersedia 
dan mudah diakses, daripada memperkirakan dan mempertimbangkan seluruh informasi yang ada. Para investor juga cenderung lebih memilih untuk berinvestasi di negara-negara yang memiliki informasi yang mudah untuk diakses.

\section{Overconfidence Bias}

Overconfidence biases merupakan suatu bentuk keyakinan atau kepercayaan diri seseorang (investor saham) dalam membuat suatu penilaian yang dianggap lebih baik daripada yang lain, serta keyakinan diri yang berlebihan terhadap keakuratan dari penilaian tersebut (Aini \& Lutfi, 2019). Dangol and Manandhar (2020) dalam penelitiannya mengemukakan bahwa faktor overconfidence bias sangat berpengaruh signifikan positif terhadap para investor dalam membuat suatu keputusan investasi. Pengaruh yang muncul disebabkan karena kegagalan investor dalam mengenali batas kemampuan diri sendiri, sehingga mengabaikan faktor-faktor atau kemungkinan lainnya yang bersifat aktual. Investor yang memiliki kecenderungan ini akan memandang dirinya lebih baik dibandingkan orang lain, sehingga menimbulkan penilaian yang terlalu optimis dan terburu-buru dengan mengabaikan faktor penting lainnya, seperti faktor risiko dalam berinvestasi.

\section{Loss Aversion Bias}

Loss aversion biases merupakan suatu kondisi pada diri seseorang (investor saham) dimana orang tersebut sangat menolak adanya risiko karena keengganannya dalam menerima suatu kerugian (Aini \& Lutfi, 2019). Mereka juga mengatakan bahwa perilaku loss aversion sendiri juga merupakan suatu bentuk perilaku yang menyimpang dan secara tidak sadar dapat menyebabkan kerugian. Al-Dahan et al. (2019) dalam penelitiannya menyatakan adanya keterkaitan yang cukup signifikan positif antara faktor loss aversion bias terhadap para investor dalam mengambil keputusan investasi. Keterkaitan tersebut dipicu karena adanya kecenderungan dari para investor yang merasa takut terhadap risiko kerugian yang melekat pada kegiatan investasi, sehingga memunculkan aksi untuk menghindari kemungkinan mengalami kerugian tersebut. Upaya para investor dalam menghindari risiko kerugian yang ada membuat pengambilan keputusan investasi cenderung lebih pesimis dan irasional.

\section{METODOLOGI PENELITIAN}

Penelitian ini merupakan penelitian kausal komparatif dan penelitian kuantitatif. Objek penelitian yang digunakan merupakan para investor saham di Kepulauan Riau. Pengumpulan data dilakukan dengan penyebaran kuesioner melalui 23 indikator, disebarkan secara langsung di Kantor Bursa Efek Indonesia Cabang Kepulauan Riau dan juga disebarkan melalui platform sosial media yang berisi group-group investor saham di Kepulauan Riau. Jumlah minimum sampel ditentukan menggunakan Teknik Hair et al., yaitu jumlah poin pertanyaan dikali 5 (lima), sehingga diperoleh jumlah minimum sampel 115 responden. Sedangkan pengambilan sampel dilakukan dengan menggunakan metode purposive sampling. Metode analisis data yang digunakan adalah metode analisis data regresi linear berganda dengan menggunakan aplikasi IBM SPSS.

\section{HASIL PENELITIAN}

\section{Statistik Deskriptif}

Jumlah data yang berhasil diperoleh berjumlah 133 responden. Selama proses pengumpulan data penelitian, terdapat 67 kuesioner yang tidak kembali, maka dari itu 
jumlah data yang digunakan dalam proses olah data adalah sebanyak 133 data. Data yang diperoleh dapat dilihat pada Tabel 1.

Tabel 1 Jumlah Kuesioner

\begin{tabular}{|l|c|}
\hline \multicolumn{1}{|c|}{ Keterangan } & Jumlah \\
\hline Kuesioner yang didistribusikan & 200 \\
Kuesioner yang kembali & 133 \\
Kuesioner yang tidak kembali & 67 \\
Kuesioner yang diolah & 133 \\
\hline
\end{tabular}

Sumber: Hasil Olah Data Mandiri (2021).

Data pada Tabel 2 di bawah merupakan hasil deskripsi dari data yang berhasil dikumpulkan dan didasarkan pada jenis kelamin, status pendidikan, usia, penghasilan, pengalaman investasi, dan kota domisili responden.

Tabel 2 Statistik Deskriptif

\begin{tabular}{|c|c|c|}
\hline Keterangan & Jumlah & Persentase \\
\hline $\begin{array}{l}\text { Jenis Kelamin } \\
\text { Pria } \\
\text { Wanita }\end{array}$ & $\begin{array}{c}102 \\
31\end{array}$ & $\begin{array}{l}76,7 \\
23,3\end{array}$ \\
\hline $\begin{array}{l}\text { Status Pendidikan } \\
\text { SMA/SMK } \\
\text { Diploma (D3) } \\
\text { Sarjana (S1) } \\
\text { Magister (S2) } \\
\text { Doktor (S3) } \\
\end{array}$ & $\begin{array}{c}52 \\
5 \\
70 \\
2 \\
4\end{array}$ & $\begin{array}{c}39,1 \\
3,8 \\
52,6 \\
1,5 \\
3,0\end{array}$ \\
\hline $\begin{array}{l}\text { Usia } \\
\text { 18-25 Tahun } \\
\text { 26-33 Tahun } \\
\text { 34-41 Tahun } \\
\text { 42-49 Tahun } \\
>\text { 50 Tahun } \\
\end{array}$ & $\begin{array}{c}71 \\
42 \\
14 \\
5 \\
1\end{array}$ & $\begin{array}{c}53,4 \\
31,6 \\
10,5 \\
3,8 \\
0,8\end{array}$ \\
\hline $\begin{array}{l}\text { Penghasilan } \\
\text { < Rp. 2.999.999 } \\
\text { Rp. 3.000.000-Rp. } 5.999 .999 \\
\text { Rp. 6.000.000-Rp. } 8.999 .999 \\
\text { Rp. 9.000.000-Rp. } 11.999 .999 \\
>\text { Rp. 12.000.000 }\end{array}$ & $\begin{array}{l}26 \\
49 \\
22 \\
12 \\
24\end{array}$ & $\begin{array}{c}19,5 \\
36,8 \\
16,5 \\
9,0 \\
18,0 \\
\end{array}$ \\
\hline $\begin{array}{l}\text { Pengalaman Investasi } \\
<1 \text { Tahun } \\
\text { 1-2 Tahun } \\
\text { 3-4 Tahun } \\
>5 \text { Tahun }\end{array}$ & $\begin{array}{c}61 \\
50 \\
14 \\
8\end{array}$ & $\begin{array}{c}45,9 \\
37,6 \\
10,5 \\
6,0\end{array}$ \\
\hline $\begin{array}{l}\text { Kota Domisili } \\
\text { Batam } \\
\text { Tanjungpinang } \\
\text { Karimum } \\
\text { Natuna } \\
\text { Bintan } \\
\end{array}$ & $\begin{array}{c}101 \\
9 \\
13 \\
3 \\
7\end{array}$ & $\begin{array}{c}75,9 \\
6,8 \\
9,8 \\
2,3 \\
5,3\end{array}$ \\
\hline
\end{tabular}


Jenis kelamin responden yang berhasil dikumpulkan terbagi atas, responden dengan jenis kelamin 'laki-laki' dengan jumlah 102 responden dan responden dengan jenis kelamin 'perempuan' dengan jumlah 31 responden. Status pendidikan responden yang berhasil dikumpulkan terbagi atas, responden dengan tingkat pendidikan SMA/SMK dengan jumlah 52 responden, responden dengan tingkat pendidikan Diploma (D3) dengan jumlah 5 responden, responden dengan tingkat pendidikan Sarjana (S1) dengan jumlah 70 responden, responden dengan tingkat pendidikan Master (S2) dengan jumlah 2 responden, dan responden dengan tingkat pendidian Doktor (S3) dengan jumlah 4 responden.

Usia/umur responden yang berhasil dikumpulkan terbagi atas, responden dengan usia/umur 18-25 tahun dengan jumlah 71 responden, responden dengan usia/umur 26-33 tahun dengan jumlah 42 responden, responden dengan usia/umur 34-41 tahun dengan jumlah 14 responden, responden dengan usia/umur 42-49 tahun dengan jumlah 5 responden, dan responden dengan usia/umur 50 tahun $\leq$ dengan jumlah 1 responden. Penghasilan perbulan responden yang berhasil dikumpulkan terbagi atas, responden dengan penghasilan $\leq \mathrm{Rp} 2.999 .999$ dengan jumlah 26 responden, responden dengan penghasilan Rp 3.000.000 - Rp 5.999.999 dengan jumlah 49 responden, responden dengan penghasilan $\mathrm{Rp} 6.000 .000$ - Rp 8.999.999 dengan jumlah 22 responden, responden dengan penghasilan $\mathrm{Rp} 9.000 .000$ - Rp 11.999 .999 dengan jumlah 12 responden, dan responden dengan penghasilan $\mathrm{Rp} 12.000 .000 \leq$ dengan jumlah 24 responden

Pengalaman investasi responden yang berhasil dikumpulkan terbagi atas, responden dengan pengalaman investasi $<1$ tahun dengan jumlah 61 responden, responden dengan pengalaman investasi 1-2 tahun dengan jumlah 50 responden, responden dengan pengalaman investasi 3-4 tahun dengan jumlah 14 responden, dan responden dengan pengalaman investasi 5 tahun $\leq$ dengan jumlah 8 responden. Kota domisili responden yang berhasil dikumpulkan terbagi atas, responden berdomisili di Batam dengan jumlah 101 responden, responden berdomisili di Tanjung Pinang dengan jumlah 9 responden, responden berdomisili di Karimun dengan jumlah 13 responden, responden berdomisili di Natuna dengan jumlah 3 responden, dan responden berdomisili di Bintan dengan jumlah 7 responden.

Pengujian signifikansi simultan (uji F) digunakan dengan tujuan untuk menunjukkan apakah keseluruhan variabel independen yang ada memiliki pengaruh kepada variabel dependen. Hasil uji F yang dilakukan dapat dilihat pada Tabel 13 dan berhasil memperoleh tingkat probabilitas atau nilai sig. sebesar 0,000 atau nilai tersebut berada di bawah 0,05, sehingga model regresi tersebut mampu mengukur variabel dependen (keputusan investasi) yang ada dan berhak untuk melanjutkan olah data lanjutan. (Ghozali, 2011).

Tabel 3 Hasil Uji F

\begin{tabular}{|c|c|c|}
\hline Model & Sig. & Keterangan \\
\hline Regresi & $0,000^{\mathrm{b}}$ & Signifikan \\
\hline
\end{tabular}

Sumber: Hasil olah data mandiri (2021)

Pengujian $\mathrm{t}$ dilakukan dengan tujuan untuk mencari tahu seberapa jauh dampak/pengaruh suatu variabel independen dalam menerangkan variabel dependen secara individual. Uji t dilakukan dengan syarat suatu variabel independen harus memiliki tingkat signifikansi pada pengujian t dengan nilai sig. (probabilitas) berada di bawah 0,05 sehingga $\mathrm{H}$ disimpulkan berhubungan signifikan terhadap variabel dependennya, 
sebaliknya apabila nilai sig. (probabilitas) berada di atas 0,05 membuat $\mathrm{H}$ dianggap tidak memiliki hubungan signifikan terhadap variabel dependennya (Ghozali, 2011).

Tabel 4 Hasil Uji t

\begin{tabular}{|l|c|c|c|}
\hline \multicolumn{1}{|c|}{ Model } & B & Sig. & Keterangan \\
\hline Representativeness Biases & $-0,071$ & 0,435 & Tidak Signifikan \\
\hline Availability Biases & 0,116 & 0,169 & Tidak Signifikan \\
\hline Overconfidence Biases & 0,120 & 0,166 & Tidak Signifikan \\
\hline Loss Aversion Biases & 0,298 & 0,001 & Signifikan Positif \\
\hline Anchoring \& Adjustment Biases & 0,189 & 0,049 & Signifikan Positif \\
\hline
\end{tabular}

Sumber: Hasil olah data mandiri (2020).

Hasil uji t untuk H1 (RB $\rightarrow$ ID) memiliki nilai standardized coefficient $B-0,071$ dan tingkat sig. 0,435 yang menggambarkan bahwa perilaku para investor yang terbiasa untuk membuat suatu keputusan hanya dengan didasarkan pada pengalaman yang dimilikinya pada masa lalu tanpa berusaha untuk menganalisis sesuatu secara mendalam (representativeness biases) tidak memiliki pengaruh yang signifikan terhadap investment dicision para investor di Kepulauan Riau. Dari sana, dapat disimpulkan bahwa hipotesis H1 ditolak, dimana perilaku buruk para investor yang terbiasa untuk membuat suatu keputusan hanya dengan didasarkan pada pengalaman yang dimilikinya pada masa lalu tidak memiliki keterkaitan dengan kualitas keputusan investasi para investor yang ikut memburuk. Hasil penelitian ini sesuai dengan hasil penelitian milik Al-Dahan et al. (2019) serta Kirera dan Mburugu (2019).

Hasil uji t untuk H2 (AB $\rightarrow$ ID) memiliki nilai standardized coefficient $\mathrm{B}$ 0,116 dan tingkat sig. 0,169 yang menggambarkan bahwa perilaku para investor yang terbiasa untuk membuat suatu keputusan dengan didasarkan atas kemudahan dan ketersediaannya informasi (availability biases) tidak memiliki pengaruh yang signifikan terhadap keputusan investasi para investor di Kepulauan Riau. Kesimpulannya, hipotesis H2 ditolak, dimana perilaku buruk para investor yang terbiasa membuat keputusan dengan didasarkan pada kemudahan dan ketersediaannya ini tidak memiliki keterkaitan dengan kualitas keputusan investasi para investor yang juga ikut memburuk. Hasil penelitian ini juga sesuai dan didukung oleh penelitian milik Rehan dan Umer (2017), serta Parveen dan Siddiqui (2017).

Hasil uji t untuk H3 (OB $\rightarrow$ ID) memiliki nilai standardized coefficient B sebesar 0,120 dan tingkat sig. 0,166 yang menggambarkan bahwa perilaku para investor dalam mengambil suatu keputusan investasi dengan kepercayaan diri yang sangat tinggi (overconfidence biases) tidak memiliki pengaruh yang signifikan terhadap keputusan investasi para investor di Kepulauan Riau. Dengan begitu, bisa disimpulkan bahwa, hipotesis H3 ditolak, dimana perilaku para investor yang begitu percaya diri dengan prediksi dan informasi yang dimilikinya tidak memiliki keterkaitan dengan kualitas dari keputusan investasi yang dibuat para investor di Kepulauan Riau. Hasil penemuan ini sama halnya dengan penemuan milik Fachrudin et al. (2017), Parveen dan Siddiqui (2017) serta Rekik dan Boujelbene (2013).

Hasil uji t untuk H4 (LAB $\rightarrow$ ID) memiliki nilai standardized coefficient B 0,298 dan tingkat sig. 0,001 yang menggambarkan bahwa perilaku para investor yang cenderung merasa takut akan adanya risiko kerugian investasi tanpa melihat keuntungan yang ditawarkan (loss aversion biases) memiliki hubungan yang signifikan positif terhadap keputusan investasi para investor di Kepulauan Riau. Karena itu, bisa disimpulkan bahwa, hipotesis $\mathrm{H} 4$ diterima, dimana perilaku para investor yang merasa 
terlalu takut akan adanya risiko kerugian dan terus berusaha untuk menghindari kerugian dalam berinvestasi sering kali menghambat pengambilan keputusan investasi yang rasional dan tepat oleh para investor di Kepulauan Riau. Hasil ini sesuai dan konsisten dengan penelitian milik Alquraan et al. (2016) serta Rekik dan Boujelbene (2013).

Hasil uji t untuk H5 (AAB $\rightarrow$ ID) memiliki nilai standardized coefficient $B$ 0,189 dan tingkat sig. 0,049 yang menggambarkan bahwa perilaku para investor yang cenderung mengambil suatu keputusan dan penilaian tertentu hanya didasarkan pada informasi awal saja (anchoring and adjustment biases) memiliki hubungan yang signifikan positif terhadap kualitas keputusan investasi para investor di Kepulauan Riau. Melalui uji t tersebut, bisa simpulkan bahwa, hipotesis H5 diterima, dimana kebiasaan buruk para investor yang hanya mengacu pada informasi awal saja terbukti mampu memperburuk rasionalitas dari keputusan investasi dari para investor di Kepulauan Riau bukan sebaliknnya. Hasil ini juga sama dan konsisten dengan penelitian milik Dangol dan Manandhar (2020), Madaan dan Singh (2019), Kirera dan Mburugu (2019), Kumari dan Sar (2017), Khan et al. (2017), Parveen dan Siddiqui (2017), serta Rekik dan Boujelbene (2013).

\section{KESIMPULAN}

Penelitian yang dilakukan untuk menganalisis pengaruh yang dimiliki oleh behavioural finance (representativeness bias, availability bias, overconfidence bias, loss aversion bias, dan anchoring \& adjustment bias) terhadap pengambilan keputusan investasi kepada 133 investor saham di Kepulauan Riau menghasilkan kesimpulan bahwa, dua dari lima variabel independen yang diuji (loss aversion dan anchoring \& adjustment bias) memiliki pengaruh yang signifikan positif terhadap pengambilan keputusan investasi investor di Kepulauan Riau, dimana variabel Loss Aversion memiliki pengaruh paling besar. Sedangkan tiga variabel independen lainnya (representativeness bias, availability bias, dan overconfidence bias) tidak berpengaruh terhadap pengambilan keputusan investasi di Kepulauan Riau.

\section{DAFTAR PUSTAKA}

Al-Dahan, N. S. H., Hasan, M. F., \& Jadah, H. M. (2019). Effect of cognitive and emotional biases on investor decisions: An analytical study of the Iraq stock exchange. International Journal of Innovation, Creativity and Change, 9(10), 3047.

Alquraan, T., Alqisie, A., \& Al Shorafa, A. (2016). Do Behavioral Finance Factors Influence Stock Investment Decisions of Individual Investors? (Evidences from Saudi Stock Market). American International Journal of Contemporary Research, 6(3), 159-169. www.aijcrnet.com

Ani, N., \& Ozari, C. (2020). Behavioural Finance: Investors Psychology. Economic, 2010.

Antony, A., \& Joseph, A. I. (2017). Influence of Behavioural Factors Affecting Investment Decision-An AHP Analysis. Metamorphosis: A Journal of Management Research, 16(2), 107-114. https://doi.org/10.1177/0972622517738833

Bursa Efek Indonesia. (2020). IDX Quarterly Statistics.

Dangol, J., \& Manandhar, R. (2020). Impact of Heuristics on Investment Decisions: The Moderating Role of Locus of Control. Journal of Business and Social Sciences Research, 5(1), 1-14. https://doi.org/10.3126/jbssr.v5i1.30195 
Fachrudin, K. R., Lumbanraja, P., Sadalia, I., \& Lubis, A. N. (2017). Analysis of heuristic behavior on investment decision. International Journal of Economic Research, 14(20), 297-309.

Kamaran, H. W., Qaisar, A., Sultana, N., Nawaz, M. A., \& Ahmad, H. T. (2020). Factors Influencing the Investor's Decision Making: The Moderating Role of Locus of Control. Journal of Asian Finance, Economics and Business, 7(12), 535-543. https://doi.org/10.13106/JAFEB.2020.VOL7.NO12.535

Khan, H. H., Naz, I., Qureshi, F., \& Ghafoor, A. (2017). Heuristics and stock buying decision: Evidence from Malaysian and Pakistani stock markets. Borsa Istanbul Review, 17(2), 97-110. https://doi.org/10.1016/j.bir.2016.12.002

Kirera, F., \& Mburugu, B. M. (2019). Impact of Heuristic Biases on Individual Investor Decision Making Process At Nairobi Securities Exchange : a Survey of Individual Investors in Meru County Impact of Heuristic Biases on Individual Investor Decision Making Process At Nairobi Securities Exch. January.

KSEI. (2019). 22 Tahun KSEI: Mendukung Pengembangan Infrastruktur Untuk Kenyamanan Investasi di Pasar Modal. 1-3. https://www.ksei.co.id/

Kumari, N., \& Sar, A. K. (2017). Cognitive and behavioral biases influencing investment performance. ZENITH International Journal of Multidisciplinary Research, 7(8), 49-62.

Madaan, G., \& Singh, S. (2019). An analysis of behavioral biases in investment decisionmaking. International Journal of Financial Research, 10(4), 55-67. https://doi.org/10.5430/ijfr.v10n4p55

Aini, N. S., \& Lutfi, L. (2019). The influence of risk perception, risk tolerance, overconfidence, and loss aversion towards investment decision making. Journal of Economics, Business \& Accountancy Ventura, 21(3), 401. https://doi.org/10.14414/jebav.v21i3.1663

Parveen, S., \& Siddiqui, M. A. (2017). Decision Making and Behavioral Heuristics of Investors in Non-Financial Sector: A Case of Pakistan Stock Exchange. Journal of Managerial Sciences: Emerging Issues in Economics and Finance (Special Edition), XI(3), 109-126. http://www.qurtuba.edu.pk/jms/default_files/JMS/special_edition/1 EIEF/07 109-126 Shagufta Parveen.pdf

Rehan, R., \& Umer, I. (2017). Behavioural Biases in Investor Decisions. Applied Investment Theory, XII(2), 29-52. https://doi.org/10.1007/978-3-319-43976-1_3

Rekik, Y., \& Boujelbene, Y. (2013). Determinants of Individual Investors' Behaviors: Evidence from Tunisian Stock Market. IOSR Journal of Business and Management, 8(2), 109-119. https://doi.org/10.9790/487x-082109119

Shah, S. Z. A., Ahmad, M., \& Mahmood, F. (2018). Heuristic biases in investment decision-making and perceived market efficiency: A survey at the Pakistan. Influence of Behavioural Factors Affecting Investment Decision. Qualitative Research in Financial Markets, 10(1), 85-110. https://doi.org/10.1108/QRFM04-2017-0033 